\title{
Oestrogen and progesterone receptor expression in mammary fibromatosis
}

\author{
S A Rasbridge, C E Gillett, R R Millis
}

\begin{abstract}
Aims-To investigate the oestrogen and progesterone receptor concentrations expressed on mammary fibromatoses to determine their responsiveness to oestrogenic stimuli.

Methods-Six mammary fibromatoses were examined using immunohistochemistry for the presence of oestrogen and progesterone receptors using antibodies against the receptor proteins. Enzyme immunoassays (EIAs) using the same antibodies were also performed in four patients. Immunohistochemical staining for pS2 protein was also carried out as a measure of functional oestrogen receptors.

Results-Neither receptor nor pS2 protein was expressed using immunohistochemistry. Very low concentrations of both oestrogen and progesterone receptors were shown by EIA.

Conclusion-These results indicate the absence of clinically important concentrations of oestrogen and progesterone receptors in breast fibromatoses and suggest that treatment directed against oestrogen is unlikely to be beneficial.
\end{abstract}

(F Clin Pathol 1993;46:349-351)

Fibromatoses are well recognised, benign, but locally infiltrative lesions which have been described in many different soft tissues. They are rare in the breast, most examples having been reports of one or two cases, until the recent publication of three larger series totalling 67 patients. ${ }^{1-3}$ Problems that may arise in patients with mammary fibromatosis are those of incorrect diagnosis as a malignancy and the possibility of local recurrence with progressive infiltration of local structures. The aetiology of these lesions is largely unknown, but there is interesting preliminary evidence that some cases may be hormonally driven. For instance, abdominal fibromatoses commonly arise in women during their reproductive years and grow vigorously during pregnancy. There have been reports of a dramatic clinical response of pelvic and abdominal lesions to the anti-oestrogen drug tamoxifen..$^{4-7}$ And there have also been some reports of oestrogen and progesterone receptor positivity in fibromatoses, including one case in the breast. ${ }^{8-10}$

We undertook an immunohistochemical study of the oestrogen and progesterone receptor content of six cases of mammary fibromatosis; in four cases EIA results were also available. Immunohistochemical staining for $\mathrm{pS} 2$, a 6.4 kilodalton protein inducible by oestrogen was also carried out. Positive pS2 staining has been reported to be predictive of an enhanced response to tamoxifen in breast carcinoma and to have prognostic value. ${ }^{11} 12$

\section{Methods}

Six patients attending the Breast Clinic of the ICRF Clinical Oncology Unit at Guy's Hospital between 1978 and 1991 were diagnosed as having a fibromatosis. Five presented with a palpable mass clinically suspicious of a carcinoma; two of the masses were located within the axillary tail of the breast. The sixth woman had a breast lesion detected on mammographic examination as part of the national screening programme but was asymptomatic. Further clinical details are given in the table.

Formalin fixed, paraffin wax embedded sections were stained with antibodies to oestrogen receptor (H222; Abbott Laboratories, Chicago, USA), progesterone receptor (KD68; Abbott) and pS2 protein (CIS biointernational, Gif-sur-Yvette, France) using a standard peroxidase conjugated streptavidinbiotin technique. To demonstrate the presence of oestrogen receptors the sections
ICRF Clinical Oncology Unit, New Guy's House, Guy's Hospital, London Bridge, London

SE1 9RT

S A Rasbridge

C E Gillett

$\mathrm{R} R$ Millis

Correspondence to:

Dr S A Rasbridge

Accepted for publication

29 September 1992
Clinical details of patients with mammary fibromatosis

\begin{tabular}{lllllll}
\hline Case No & 1 & 2 & 3 & 4 & 5 & 6 \\
\hline Age (y) & 30 & 20 & 34 & 27 & 53 & 56 \\
Site & $\begin{array}{l}\text { Supra-areolar } \\
\text { Right breast }\end{array}$ & $\begin{array}{l}\text { Upper outer } \\
\text { quadrant }\end{array}$ & $\begin{array}{l}\text { Periareolar } \\
\text { Right breast }\end{array}$ & $\begin{array}{l}\text { Axillary tail } \\
\text { Left breast }\end{array}$ & $\begin{array}{l}\text { Axillary tail } \\
\text { Left breast }\end{array}$ & $\begin{array}{l}\text { Lower outer } \\
\text { quadrant } \\
\text { Right breast }\end{array}$ \\
& Breast lump & $\begin{array}{l}\text { Breast lump } \\
\text { Symptoms }\end{array}$ & Breast lump & "Breast" lump & "Breast" lump & $\begin{array}{l}\text { Asymptomatic } \\
\text { Clinical size }\end{array}$ \\
Mammography & $0.5 \mathrm{~cm}$ & $1.2 \mathrm{~cm}$ & $2 \mathrm{~cm}$ & $9 \cdot 0 \mathrm{~cm}$ & $4.5 \mathrm{~cm}$ & $\begin{array}{l}0.8 \mathrm{~cm} \\
\text { (on } x \text {-ray) }\end{array}$ \\
& Not done & Not done & Not done & Not done & Not done & $\begin{array}{l}\text { Spiculated } \\
\text { tissue density }\end{array}$ \\
\hline
\end{tabular}




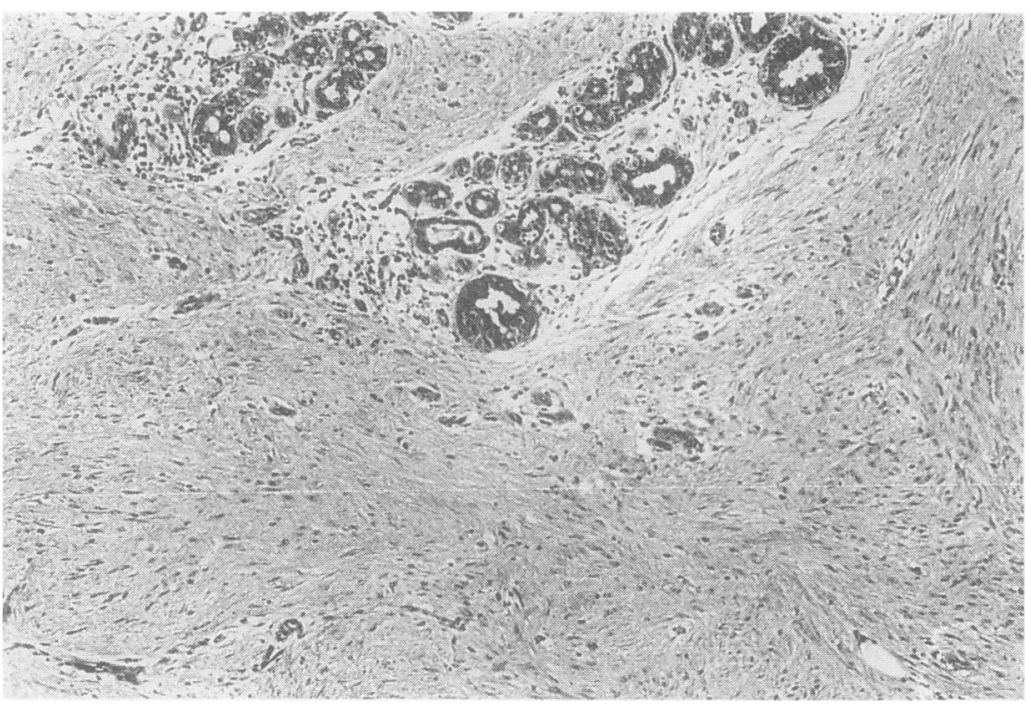

Figure 1 Mammary fibromatosis: a cellular fibroblastic proliferation running between and separating the mammary lobules.

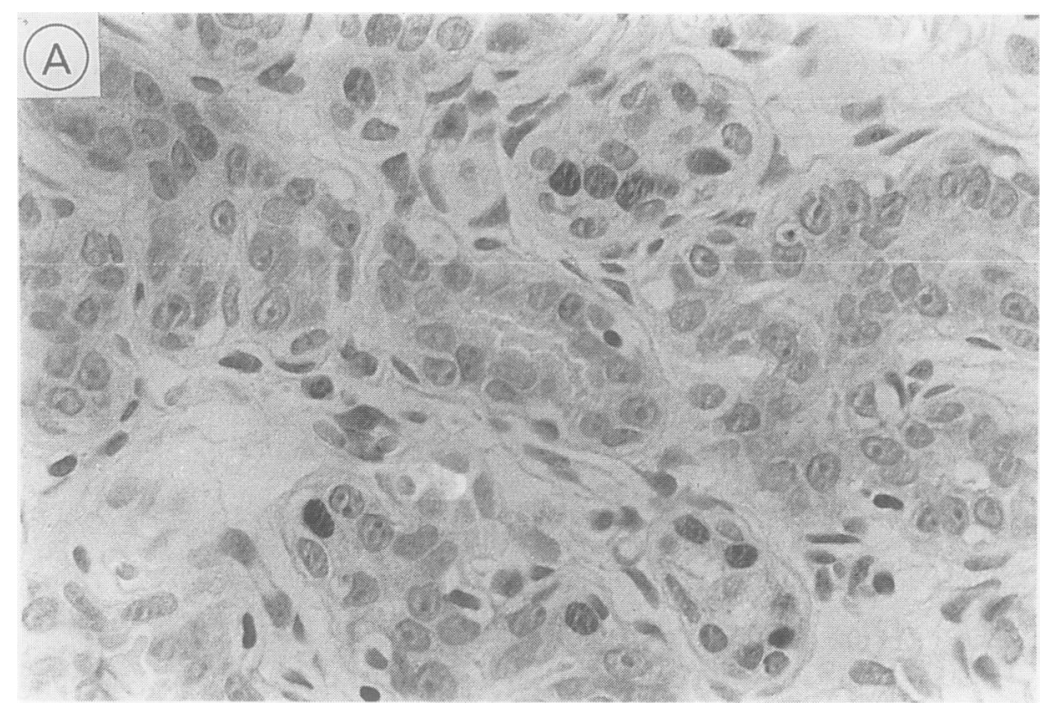

Figure $2 A \quad$ Breast tissue adjacent to a fibromatosis showing positive nuclear staining for oestrogen receptor.

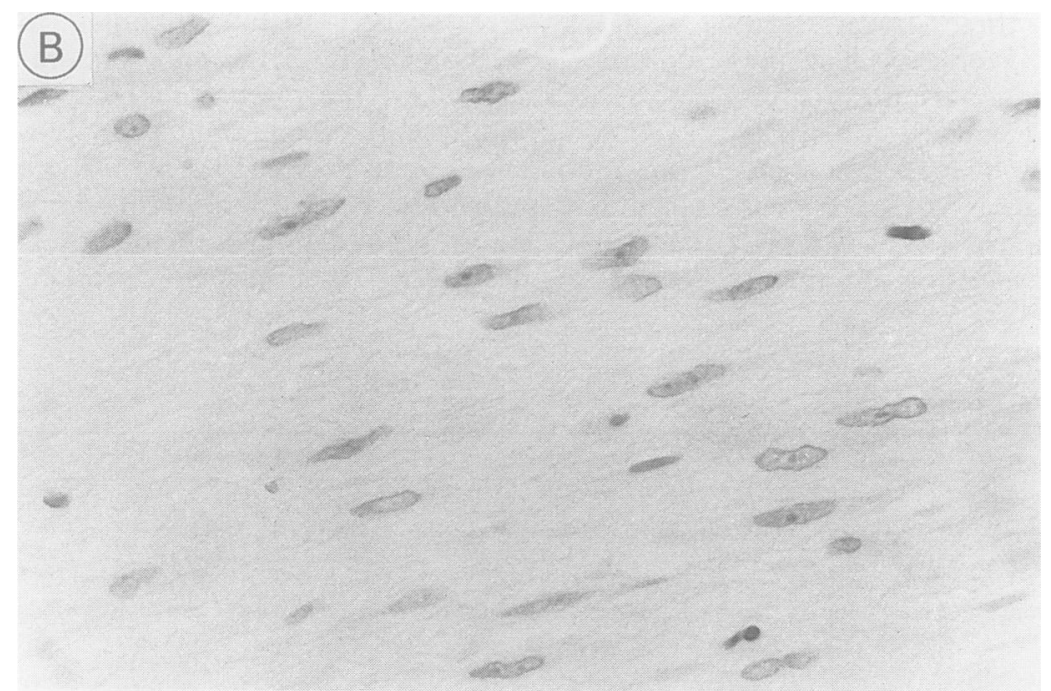

Figure $2 B$ Fibroblasts within the same fibromatosis do not show any staining with this antibody (H222). required prior treatment with Pronase E for 9 minutes to expose the antigen. Antibodies to both the receptors were incubated with the sections overnight at room temperature; $\mathrm{pS} 2$ could be detected after incubation for 1 hour.

Fresh tissue was snap-frozen in liquid nitrogen and homogenised in a tissue dismembranator. Cytosol fractions were prepared by extraction in TRIS/EDTA/sodium molybdate buffer and centrifugation at $4^{\circ} \mathrm{C}$. An EIA kit from Abbott Laboratories was then used to assay oestrogen and progesterone receptors.

\section{Results}

Four patients were premenopausal; none was pregnant or taking oral contraceptives at the time of diagnosis, although three patients had used oral contraceptives between nine and four years previously. A fifth woman had undergone a bilateral salpingo-oophorectomy 14 years earlier without receiving any hormonal replacement therapy. Follow up of four patients at between one and 11 years showed no recurrence. One woman had a recurrence of her lesion within two years but no further problems for seven years after a second resection. The remaining patient was lost to follow up after her initial treatment.

The macroscopic appearances of the lesions varied: in two cases the specimen showed firm but otherwise unremarkable fibro-fatty breast tissue without a discrete mass. In the others a contracted, firm, pinkish-white, stellate mass resembling a small carcinoma was apparent within otherwise fatty tissue.

Light microscopic examination of each case showed a poorly circumscribed lesion composed of spindle shaped fibroblasts surrounded by coarse bands of rather hyaline collagen. The fibroblastic proliferation had an infiltrative edge extending into the fatty stroma and entrapping the normal structures of the breast when these were present. Neither mitotic activity nor cellular atypia was seen (fig 1).

Immunohistochemical staining for oestrogen and progesterone receptors was negative in all cases (fig 2A), despite good positive controls and occasional positive nuclei within breast ductal epithelial cells adjacent to some fibromatoses (fig 2B). No staining for $\mathrm{pS} 2$ was seen in either the fibromatoses or in normal breast tissue, but a control mammary carcinoma specimen was clearly stained.

EIA of oestrogen receptor content in four cases $(2,4,5$ and 6$)$ gave values of between 5 $\mathrm{fmol} / \mathrm{mg}$ and $7 \mathrm{fmol} / \mathrm{mg}$ (of cytosol protein) with progesterone receptor concentrations between $0 \mathrm{fmol} / \mathrm{mg}$ and $9 \mathrm{fmol} / \mathrm{mg}$.

\section{Discussion}

The aetiology of fibromatoses is unknown. Physical, hormonal, and genetic factors have been implicated. These are not necessarily mutually exclusive as a combination of factors may be involved. The aetiological factors may 
differ in the different subgroups of fibromatosis.

The breast is responsive to female sex hormones-its development depends on oestrogen and even the mature breast undergoes cyclical epithelial and stromal changes in response to hormonal fluctuations during the menstrual cycle. ${ }^{1314}$ The proliferative activity of epithelial cells has been shown to vary with changing concentrations of oestrogen and progesterone, but little is known about the regulation of proliferation in stromal cells. ${ }^{15}$ Strongly positive immunostaining for progesterone receptors, however, has been observed in the hyperplastic stromal reaction known as pseudoangiomatous hyperplasia, ${ }^{16}$ especially when arising independently of mammary hamartomas. There is therefore some support for the suggestion that proliferation of breast stromal cells is hormonally regulated.

There are reports of clinical responses to "anti-oestrogen" treatment (testacolone or tamoxifen) in patients with abdominal wall or pelvic fibromatoses, with occasionally dramatic results. ${ }^{4-7}$ Assay of receptor content from 10 such masses has shown either negative results or very low receptor concentrations: specifically, five cases had detectable oestrogen receptor concentrations of between 0.03 and $4.6 \mathrm{fmol} / \mathrm{mg}$. In two cases progesterone receptor concentrations of 9.4 and 0.2 $\mathrm{fmol} / \mathrm{mg}$ were found. ${ }^{89}$ Conflicting results have been seen, however, in the only two cases of mammary fibromatosis examined. One was associated with high progesterone receptor concentrations of $74 \mathrm{fmol} / \mathrm{mg}$ and oestrogen receptor concentrations of 10 $\mathrm{fmol} / \mathrm{mg}^{10}$; another group found that their case was completely negative for both receptors. $^{3}$

In view of the contradictory evidence we were prompted to investigate the receptor status of our cases of breast fibromatosis. All six cases were negative for oestrogen and progesterone receptors as judged by immunostaining. Although the antibodies used were originally used in frozen sections, recent changes in methodology have allowed them to be used in fixed tissue with reliable results, comparable with those seen in frozen tissue. ${ }^{1718}$ Several studies have shown an $85-95 \%$ correlation between the results of biochemical assays and immunohistochemical staining of both receptors. ${ }^{1718}$ In our four cases, where suitable material was available, the EIA showed low but detectable concentrations of receptors. In our laboratory, had these levels been present in a breast carcinoma, they would have been regarded as "negative" insofar as they predicted a likely response to endocrine treatment.

The cytoplasmic protein pS2 is induced by exposure to oestrogen and although of unknown function, has been associated with an enhanced response to tamoxifen in breast carcinoma even in oestrogen receptor negative tumours. ${ }^{112} \mathrm{pS} 2$ may therefore be a marker of a functional oestrogen receptor which does not express the normal epitopes detected by the $\mathrm{H} 222$ antibody. In case the putative receptors on fibromatosis were of this nature we stained for pS2 protein. This, again, was negative in all cases.

These results indicate that if oestrogen and progesterone receptors can be found in mammary lesions, the concentrations are usually low and suggest that anti-oestrogen treatment is unlikely to be of benefit. However, other mechanisms such as induction of transforming growth factor $\beta 1,{ }^{19}$ which can act as a potent growth inhibitor, may underlie the reported responses to tamoxifen.

Gump FE, Sternschein MJ, Wolff M. Fibromatosis of the breast. Surg Gynecol Obstet 1981;153:57-69.

2 Wargotz ES, Norris HJ, Austen RM, Enzinger FM Fibromatosis of the breast. Am $\mathcal{F}$ Surg Pathol 1987;11: $38-45$

3 Rosen PP, Ernsberger D. Mammary fibromatosis. Cancer 1989;63:1363-9.

4 Sauven P. Muculo-aponecrotic fibromatosis treated by surgery and testolactone. F Roy Soc Med 1982;75:281-3.

5 Kinzbrunner B, Ritter S, Domingo J, Rosenthal J. Remission of rapidly growing desmoid tumours after tamoxifen therapy. Cancer 1983;52:2201-4.

6 Waddel WR, Gerner R, Reich MP. Nonsteroid antiinflammatory drugs and tamoxifen for desmoid tumours and carcinoma of the stomach. $₹$ Surg Oncol 1983;22: and carcin $197-211$.

7 Klein WA, Miller HK, Anderson M, DeCosse JJ. The use of indomethacin, sulindac and tamoxifen for the treatment of desmoid tumours associated with familial polyposis. Cancer 1987;60:2863-8.

8 Chaudhuri P, Walker MJ, Beattie CW, Das Gupta TK Presence of steroid receptors in soft tissue sarcomas of diverse histological origin. Cancer Res 1980;40:861-5.

9 Hayry P, Reitamo JJ, Bikho R, et al. The dermoid tumour III. A biochemical and genetic analysis. Am $\mathcal{f}$ Clin Pathol 1982;77:681-5.

10 Pierce VE, Rives DA, Sisley JF, Allsbrook WC. Estradiol and progesterone receptors in a case of fibromatosis. Arch Pathol Lab Med 1987;111:870-2.

11 Foekens JA, Rio M-C, Seguin P, van Putten WLJ, Fauque J, Nap M. Prediction of relapse and survival in breast cancer patients by $\mathrm{pS} 2$ protein status. Cancer Res 1990;50:3832-7.

12 Walker RA, Dearing SJ, Rye PD, Dookeran KA. The significance of $\mathrm{pS} 2$ immunoreactivity in primary breas carcinoma. F Pathol (suppl) 1992;167:131A.

13 Vogel PM, Georgiade NG, Fetter BF, Vogel FS, McCarty KS. The correlation of histologic changes in the human breast with the menstrual cycle. Am $\mathcal{F}$ Pathol 1981;104: 23-34.

14 Longacre TA, Bartow SA. A correlative morphologic study of human breast and endometrium in the men strual cycle. Am $\mathcal{F}$ Surg Pathol 1986;10:382-93.

15 Anderson TJ, Battersby S, King RJB, McPherson K, Going JJ. Oral contraceptive influences resting breas proliferation. Hum Pathol 1989;20:1 139-44.

16 Anderson C, Ricci A, Pedersen CA, Cartun RW Immunocytochemical analysis of oestrogen and progesterone receptors on benign stromal lesions of the breast. Am $\mathcal{F}$ Surg Pathol 1991;15:145-9.

17 Raymond WA, Leon A S-Y. Oestrogen receptor staining of paraffin embedded breast carcinomas following short fixation with formalin: A comparison with cytosolic and frozen section receptor analyses. $\mathcal{F}$ Pathol 1990;160: 295-303.

18 Wilbur DC, Willis J, Mooney RA, Fallow MA, Moynes R, Di Sant D'Agnese PA. Estrogen and progesterone receptor detection in archival, formalin fixed, paraffin embedded tissue from breast carcinomas. A comparison of immunohistochemistry with the dextran coated charcoal assay. Mod Pathol 1992;5:79-84

19 Butta A, MacLennan K, Flanders KC, et al. Induction of transforming growth factor $\mathrm{B} 1$ in human breast cancer in vivo following tamoxifen treatment. Cancer Res 1992;52:4261-4 